\title{
Critical success factors for an outsourcing strategy in a multi-campus university setting: A case of University for Development Studies, Ghana
}

\begin{abstract}
Job Asante
Faculty of Integrated Development Studies, University for Development Studies, WA Campus, P.O. Box UPW 520, WA, Ghana.

E-mail: jobasante72@yahoo.com. Tel: 0244515357/ 0209248395.

Accepted 19 $9^{\text {th }}$ November, 2018.

Abstract. The objective of the research is to explore why some Higher Educational Institutions fail to get the benefits of outsourcing. The research aimed to achieve this by first establishing the critical success factors for outsourcing in a University and then discovering how well universities implement these factors. Respondents from the University for Development Studies, Wa campus were requested to rank on a Likert Scale the importance of and their performance on these critical factors. The importance and performance on these factors were ranked based on the means and standard deviations of their responses. Findings include a list of the most critical success factors for outsourcing in the University for Development Studies (UDS), Wa Campus. It was also discovered that the amount of effort going into these factors was disproportional to the level of importance of the factors. Only $25 \%$ of the respondents said outsourcing was a success. A framework was recommended to be used by the university to improve their outsourcing.
\end{abstract}

Keywords: Outsourcing, strategy, success factors, efficiency, non-core activities.

\section{INTRODUCTION}

The future of Higher Education in Ghana depends continually in searching for cheaper and more efficient ways of provision of educational services to their clients. Ways of taking a low quality resource and exploiting it in an economically viable way have to be found to achieve a sustainable future in higher education. The pressure to remain in competitive markets and to meet the demands of government has forced educational operators to be very vigilant on all expenditure. Outsourcing is seen as one way for ensuring that organizations or departments remain lean and contribute more value to the organization at the same time (Embleton and Wright, 2000). Linder (2004) describes outsourcing as one effective way to "replace the engine of an airplane while it is still in the air". Businesses in both private sector and the public sector are now into the practice. Across the globe and in Africa, public sector and private sector are
Alike. The practice of outsourcing is certainly a contentious issue and is something everyone has an opinion on. It has found its feet and is now becoming a recognized and legitimate business practice.

Outsourcing as defined by Kenneth and Farrington (2006) "is a management strategy by which major noncore functions are transferred to specialist, efficient, external providers". Stated differently, it refers to the process by which a company contracts with another company to provide services that might otherwise be performed by in-house employees. Most often such jobs outsourced are what are considered "non-core" to the organization. This means that such an activity is not the main focus or stay of the organization. Examples of such areas mostly outsourced are catering, auditing, security, medical, maintenance, transport, training, information, legal and among others. 
The general principle to adopt in outsourcing is to outsource non-core activities. This is to allow for focus on the major practices and outsource functions of which the organization has no distinctive competence. The distinction between core and non-core activities may however not always be that simple, and as pointed out by Linder (2004), what is non-core today may become core tomorrow and vice versa. Also, what may be non-core to one organization may be core to another organization.

Most outsourcing decisions are based on the difference in the cost of purchasing a product or service from an external supplier, compared to the cost of producing the item or providing the service in house. It means that clients before the decision to outsource, benchmark cost data for a baseline on which to structure the providers' services and point to use in measuring the outsourcing decision. A lot of cost analysis pertaining labour, material, variable overhead cost, fixed overhead cost among other cost elements considered essential in arriving a decisive decision are all factored. More also, business costs are basically a function of two factors; cost factor number one actually associated with writing cheque; thus actually paying for something.

Cost factor number two is not as obvious. This is where the costs are either disguised in the form of some other line item, or not even on a balance sheet. These costs are the main concern critical for outsourcing. While outsourcing may prove highly beneficial particularly in cost saving for most companies, others might not see it so. It is important that each individual company accurately assess their needs to determine if outsourcing is a viable option and the critical success factors for smooth implementation of outsourcing strategy. Higher Education is not far from the practice and a firm in the industry of which much is to be talked about is University for Development Studies. According to one estimate, 20\% of the activities in the industry are outsourced to third party providers or outsourcers. The providers of the outsourced services could be within the country in which the client company operates or outside the country of operation (offshore).

Outsourcing gained prominence and was originally driven by the desire to reduce cost especially in labourintensive business processes. This practice which is rootfeeted globally to provide alternative cost-cut down strategy, also aim at providing an opportunity for businesses to be managed in such a competitive manner. However, higher educational institutions in Ghana which adopted the practice to outsource most of their non-core activities, although with reaping benefit, there seem to be difficulties and a stick out of neck.

With reference to UDS, with its quest to cut down cost for effective operation is considering to outsource most of its services ranging from cleaning, catering, security among others. Recent news tells that, security which is to be outsourced has now been adopted to run in-house as "Owner Provider". It spells out that, despite the benefits associated with the strategy, there are unearthed challenges which militate against its smooth practice. It is in respect of the above the study seeks to find out" Critical Success Factors for an Outsourcing Strategy in a Multi- Campus University Setting": A case of University for Development Studies.

\section{Emerging issues of critical success factors}

This section seeks to examine the emerging issue of critical success factors for an outsourcing strategy. It includes a review of current, relevant and significant views (what we know) about general outsourcing and critical success factors for an outsourcing strategy and gives an overall assessment of previous researches.

\section{Strategy}

Organizations, their strategies, their structures and the management of them become ever more complex. Among the reasons for this are the increasing turbulence and propensity to change in the business environment, and the tendency for multiproduct multinational organizations to become commonplace. Organizations need to know where they are, where they are going and how to manage the changes. Managers in these organizations need to know where their roles fit in relation to the whole and how they can contribute to strategic developments and changes.

Thompson and Martin (2001) explains that strategies are means to ends. All organizations, large and small, profit-seeking and not-for profit, private and public sector, have a purpose, which may or may not be articulated in the form of a mission and/or vision statement. Strategies relate to the pursuit of this purpose. Strategies must be created and implemented.

According to Davies (2000), strategy outlines how the company's goals and objectives will be achieved. He positions strategy in a triangle with resources and policy. Policy defines the goals and objectives that help develop and sustain direction. Resources are the material and methods that provide the 'with-what' means for achieving policy. Davies (2000) defines outsourcing as a resource method. Gottschalk and Solli-Sather (2005) also states that according to the resource-based theory of the firm, outsourcing is a strategic decision which can be used to fill gaps in the firm's resources and capabilities. According to this theory outsourcing on its own is not a strategy. It is an abuse of the term strategy to then use it to describe outsourcing. In 'What is strategy' Porter (2000) protests that a number of management tools and techniques, total quality management, benchmarking, time-based competition, outsourcing, partnering, reengineering and change management have taken the place of strategy.

Outsourcing can be used to support a number of strategies, namely focus, scaling without mass, disruptive 
innovation and strategic repositioning.

According to Leavy (2004), many companies see outsourcing as a way to hire best-in-class companies to perform routine business functions and then focus corporate resources on key activities in their value chain where the impact will be felt the most by the customer. Gottschalk and Solli-Saether (2005) instead of focus, talk of the theory of core competencies. This theory suggests that activities which are not core-competencies should be considered for outsourcing with the best-in-the-world suppliers.

According to Arnold (2000), only the goods and services which are considered to be core competencies (that is, with highest specificity) should be produced internally. Core competencies should not be outsourced. That is because core competencies are the activities that provide long-term competitive advantage. If the supplier markets were efficient, companies would outsource all activities except core competencies. Core competencies consist of three elements. Firstly, they differentiate the company from its competitors. In the eyes of the customers the characteristics of the core competency must be essential. Secondly, competitive advantage must be sustainable, and the resources and know-how for the product must remain unique. It must be possible to protect the core competency against imitation by competitors. Thirdly, to be core competencies, these resources must be usable for multiple purposes. Ellram and Billington (2001), on the other hand, have listed characteristics of core competencies as follows. Core competencies are a company's unique sources of leverage in the value chain. They are areas where the company can dominate and perform activities important to the customers better than others.

In scaling without mass, outsourcing is said to offer companies the opportunity to grow in market presence without a corresponding expansion in organizational size or bureaucracy. Outsourcing is said to allow firms to retain their entrepreneurial speed and agility, which they would otherwise sacrifice in order to become efficient as they expand.

According to the neoclassical theory companies will justify their sourcing strategy based on evaluating possibilities for production cost savings. The question on whether to outsource or not is a question of whether the market place can produce products and services at a lower price than through internal production (Gottschalk and Solli-Sather, 2005). Low-cost leadership strategy focuses on gaining competitive advantage by having the lowest cost in the industry. In order to achieve a low cost advantage an organization must have a low cost leadership strategy. The organization must be willing to discontinue any activities in which they do not have a cost advantage and should consider outsourcing activities to other organizations with a cost advantage (Allen et al., 2006).

Historically, in the absence of developed external markets, organizations sourced a wide range of upstream and downstream activities in-house. Developments in the scope of external supply markets continue to challenge the strategy of vertical integration, allowing companies to extend the use of outside supply (Jennings, 2002).

\section{Outsourcing}

Franceshini et al. (2003) describe outsourcing as a management approach by which an organization delegates some non-core functions to specialized and efficient service providers. Outsourcing is also described as the procurement of products or services from expertise that is external to the organization (Bujisic et al., 2014; Embleton et al., 2000). Embleton et al. (2000) differentiated outsourcing from contracting-out. Contracting-out refers to work assigned to an outside supplier on a job-by-job basis. Outsourcing on the other hand entails a long-term relationship between supplier and beneficiary with a high degree of risk sharing. Zhu et al. (2001) describe outsourcing as the process of transferring responsibility for a specific business function from an employee group to a non-employee group. Farrington and Lyson (2006) also explained that outsourcing is a management strategy by which major non-core functions are transferred to specialist, efficient, external providers". Outsourcing has seen an evolution from the traditional to the strategic. It is considered traditional if a process not considered critical for the organization e.g. cleaning services are outsourced (Franceschini et al., 2003). According to them strategic outsourcing is when companies outsource everything except those core activities in which they could achieve a unique competitive edge. Fill and Visser (2000) mention other types of outsourcing, namely capacity and noncapacity outsourcing. Capacity outsourcing refers to those activities being outsourced which are also executed by the client. Non-capacity outsourcing concerns the outsourcing of activities which are no longer pursued by the client. Other researchers refer to outsourcing as a continuum where at one extreme there is selective outsourcing and at the other is full outsourcing. Full outsourcing is when the vendor is in charge of all activities within a process. In this research the strategic perspective of full outsourcing or non-capacity outsourcing will be considered. It is felt that the maximum benefits will be achieved if full outsourcing is conducted as opposed to partial outsourcing.

According to Horngren (2000), outsourcing is the process of purchasing goods and services from outside vendors rather than producing the same goods or services within the organization, which is called in sourcing. Decisions for a producer of goods or services to in-source or outsource are also called make-or-buy decisions, sometimes qualitative factors dictate management make-or-buy decision. The most important factors in make-or-buy decision are quality 
dependability of supplier and cost. As a matter of fact, not only are the activities transferred, but the factors of production and decision rights often are, too. Factors of production are the resources that make the activities occur and include people, facilities, equipment, technology and other assets. Decisions rights are the responsibilities for making decisions over certain elements of the activities transferred.

The change evoked with outsourcing is rather permanent than temporary by nature. Quelin and Duhamel (2003) have defined outsourcing as the operation of shifting a transaction previously governed internally to an external supplier through a long-term contract. Outsourcing involves also the transfer of staff to the vendor.

Besides cost and profitability considerations, sourcing decisions also involve consideration of strategy issues, detailed financial evaluation, efficiency and risk dimensions relating to supplier quality, lead times and delivery reliability (Tayles and Drury, 2001).

Barthelemy and Geyer (2001) argued that, companies should outsource everything except those special activities in which they could achieve a unique competitive edge but also take transaction costs into account as most supplier markets are imperfect and outsourcing entails unique transaction costs; searching, contracting, controlling, and recontracting, that at times may exceed the transaction costs of having the activity directly under management's in-house control. Transaction Cost Economics is mainly concerned with transaction and production cost efficiency, the management literature has sought to integrate performance elements in outsourcing framework.

As Greaver (2001) puts it, the outsourcing initiative becomes strategic when it is aligned with the organization long-term strategies, and when the typical outsourcing benefits have emerged over several years, the results, either positive or negative, will be significant to the organization. Strategic outsourcing takes a higher level by asking fundamental question about outsourcing's relevance to the organization and its:

1. Vision of its future.

2. Current and future core competencies.

3. Current and future structure.

4. Current and future costs.

5. Current and future performance.

6. Current and future competitive advantage.

Four general themes seem to be dominant outcomes of research on keys to successful outsourcing. These are make-or-buy analysis, selection of right vendor, vendor relationship management and stakeholder management.

Mclvor (2000) proposes a general guideline on the factors that should be considered in making the outsourcing decision. These are cost analysis, associated risks, supplier influences and a strategic perspective. Jennings (2002) suggests that the outsourcing decision varies between firms within industries due to differences in each organization's context. He gives the following contextual factors that have to be considered namely, capability, cost, technology, supply and product market conditions. These conditions will enable a consideration of the outsourcing decision through a focus upon its implications for competitive advantage. Fill and Visser (2000) also stress the importance of paying attention to the context within which outsourcing decisions are made. They state that decisions based on cost are insufficient as are decisions based on cost and strategy alone. They propose a model consisting of three factors to be used in making the outsourcing decision namely:

1. An analysis of contextual factors represented by an organization's particular internal and external conditions.

2. The strategic and structural aspects associated with an organization's decision to reconfigure, and

3. The transaction costs associated with the process or activity under review.

If the outsourcing contract is not preceded by careful strategic planning and thorough risk assessment, it may result in financial loss, decreased shareholder value, damaged company reputations or even destruction of the business (Jiang, 2005). They further state that the awareness of possible risks incurred when outsourcing, will enable decision makers and stakeholders to make informed decisions and draw up contingency and mitigation strategies. A holistic approach to outsourcing, one that evaluates both the risks and rewards, is crucial (Frost, 2000). Robust risk management processes are needed to ensure that risks are identified and addressed so that the real opportunities to increase shareholder value provided by outsourcing can be realized (Frost, 2000). According to Frost (2000), the use of outsourcing as a strategic management tool increases operational risk in a number of ways namely:

1. Lack of strategic clarity before outsourcing takes place. 2. Big size of outsourcing transactions with success or failure making a huge difference to an organization's overall financial position.

3. Initial business disruption during handover of control to a third party and termination.

4. Service contract becoming outdated and inflexible as strategic direction of an organization changes.

5. Outsourcing vendor not being more efficient in running a function.

For success the following risk management measures have to be taken:

1. Evaluation of risks of losing critical skills.

2. Evaluation of risk of access to private and sensitive data. 

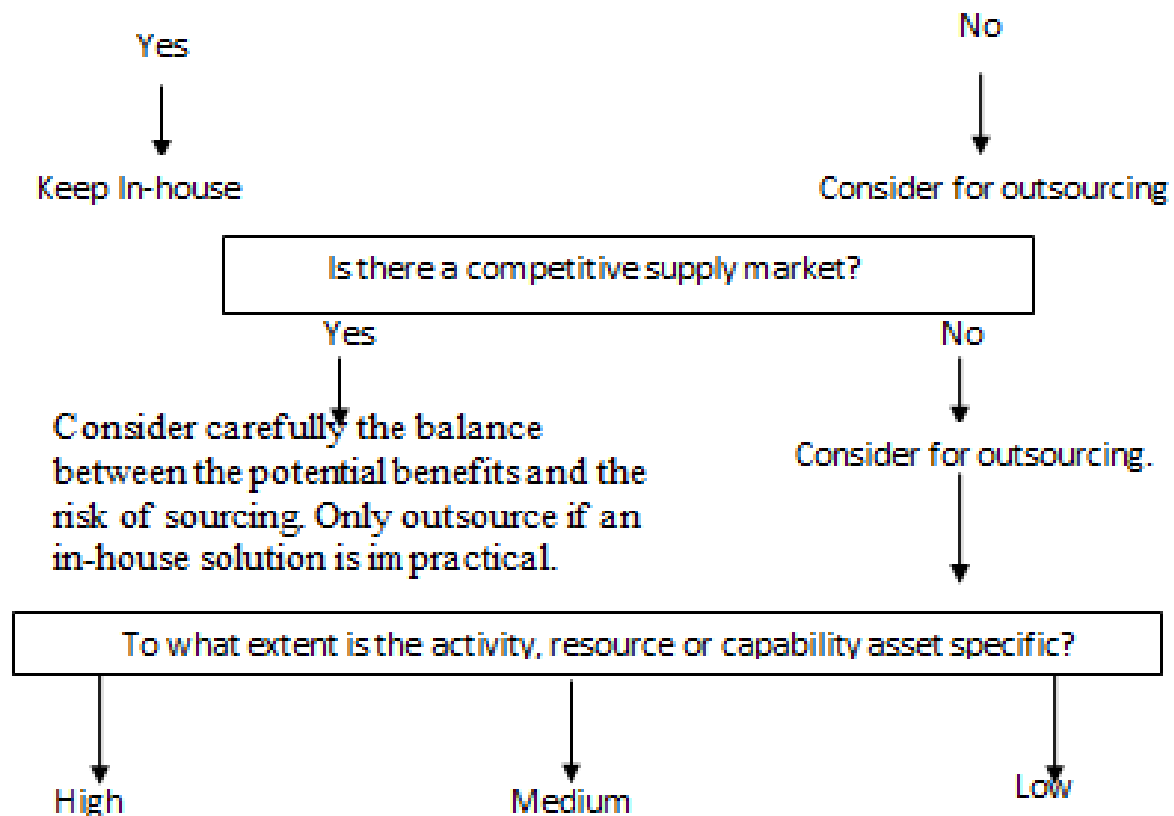

Keep in-house

Outsource and develop bilateral contract

Outsource and use shortterm contracts

Figure 1. A risk management model for an outsourcing strategy. Source: Author (2016).

3. Establishment of contingency and mitigation plans for above mentioned risks.

A risk management model has been constructed for outsourcing. The first issue in the model, illustrated in the figure below is whether the activity planned to be outsourced is responsive for competitive advantage or not. If the answer is affirmative, the activity is better to keep in-house, otherwise outsourcing is an alternative "core competency". In the second phase the decision makers must avoid monopolistic or oligopolistic supply markets. In the third phase the asset-specificity of an activity categorized in three different categories: high, medium, and low. The issue here is how to manage the risk of post-contractual dependency. If the assetspecificity is high, it is better to keep this kind of activity in-house. In case the asset-specificity is medium, outsourcing with a bilateral contract with the supplier is recommended, and when the asset-specificity is low, outsourcing with a short-term contract is suitable (Figure 1).

Embleton (2000) proposes that a company determine whether outsourcing the service will have a negative cultural impact. Other researchers stress the need to consider cultural fit during vendor selection. The critical success factor is to ensure that outsourcing will not have a negative cultural impact.

It is essential that the right vendor or mix of vendors be chosen after the decision to outsource has been reached (Franceschini et al., 2003). They emphasize that time and money has to be spent to ensure the right vendor. They further suggest that an external benchmarking of vendor be conducted. They suggest that a client decide whether to cooperate with a single vendor, multiple vendors or integrated suppliers. Embleton et al. (2000) emphasize the importance of similarities in culture as well as ensuring that both client and vendor move in the same strategic direction. They also emphasized the importance of determining the level of interest and capabilities of the vendors. Campbell (2005) emphasizes the importance of ensuring that unbiased evaluations of vendors are carried out. Embleton et al. (2000) further stresses the importance of vendor expertise in the activity being outsourced. Bujisic et al. (2014) added the following factors to the planning and conduct of the acquisition process:

1. Purchasing representation on the supplier selection team

2. Competence factors to use in evaluating suppliers (e.g. flexibility, understanding the company's business, technology leadership). Suppliers with a good understanding and interest in outsourcing firms' business are said to be better positioned to develop mutually beneficial goals.

Outsourcing is said to be an emotional decision, especially for the first time outsourcer, and the success and longevity of an outsourcing arrangement depend greatly on the success of the vendor/client relationship 


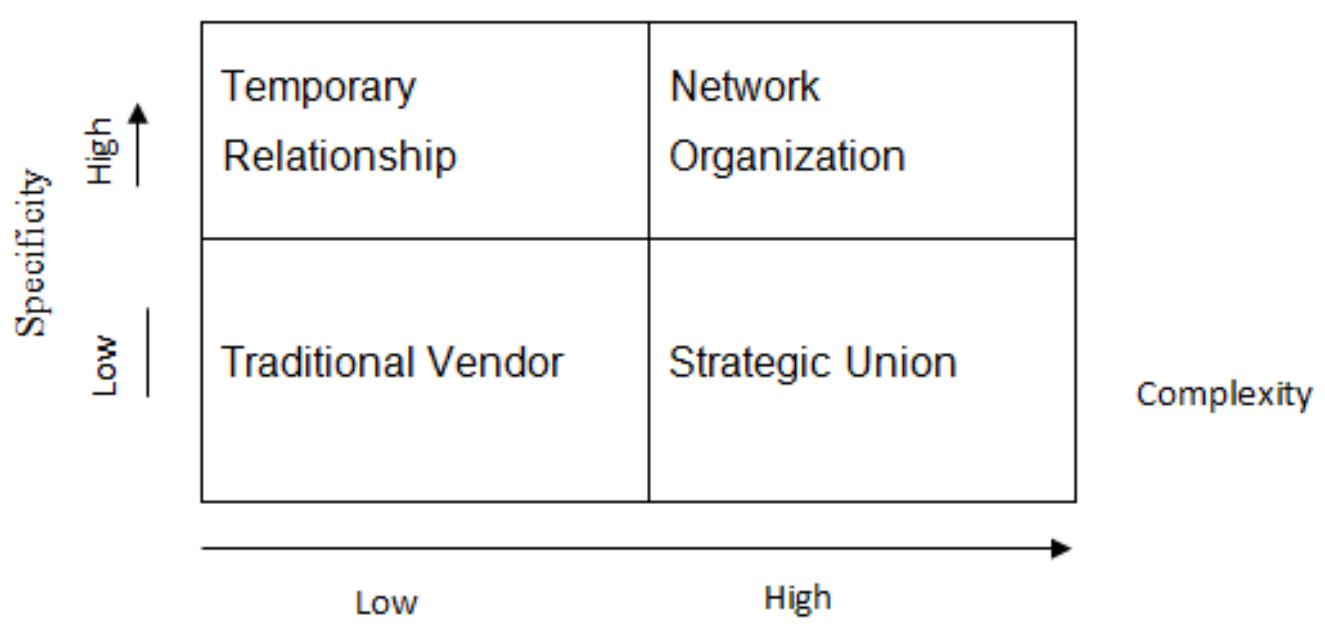

Figure 2. Scheme of the four types of outsourced-outsourcer relationships based on different levels of complexity and specificity. Source: Franceschini et al. (2003).

(Webb and Laborde, 2005). Bujisic et al. (2014) came up with vendor-selection criteria that emphasize, among other things, the need to ensure cultural fit between outsourcer and outsourcee. Bujisic et al. (2014) propose regular reviews coupled with close monitoring in managing the contract. They also advocate the involvement of senior management in relationship management. Bujisic et al. (2014) offer the following advice on relationship management match the specific needs of the organization with the supplier's capabilities so as to develop a contract around a shared vision:

1. Involve a cross-functional team to assess the company's needs.

2. Involve same cross-functional team in managing the contract.

3. Evaluate supplier performance on twin dimensions of technical and functional quality.

4. A modular, all-inclusive contract, focusing on a specific operation is better than a turnkey contract, only focusing on a specific function.

Mclvor (2000) proposes relationship analysis in the outsourcing decision whereas other researchers stress it under the relationship or contract management theme. Franceschini et al. (2003) propose that an organization evaluate the type of relationship it requires based on two main characteristics, that is, specificity and complexity of the process to be outsourced. Specificity refers to the level of re-utilization of the considered process for many different uses while complexity refers to the difficulty of monitoring and defining contract terms and conditions of the outsourcing process. A combination of these two characteristics gives rise to four possible types of relationships namely traditional vendor, temporary relationship, strategic union and network organization (Figure 2).
Barthelemy and Geyer (2001) suggested that generally there are seven steps to successful outsourcing namely:

1. Planning initiatives; Assess risks, announce initiative, form project team, engage advisers, train team, acquire other resources, address issues (Resource Management, Information Management and Project Management), and set objectives.

2. Exploring strategic implication; understand organization's (vision, core competencies, structure, transformation tool, value chain and strategy), Determine - decision rights, contract length, termination date, align initiative.

3. Analyzing cost and performance; Measure activity cost, project future cost, measure performance (existing and future, and cost of poor performance), Benchmark costs/performance, Determine- specific risks, asset values, "make" total costs, pricing model and final targets. 4. Selecting providers; Set qualification, set evaluation criteria, identify providers, screen providers, Draft Request for Proposal (RFP), evaluate proposals (qualifications, costs), perform due diligence, determine "buy" total costs, shortlist providers, finalist provider, review with senior management.

5. Negotiating terms; plan negotiation, address -high level issues and deal breakers, prepare term sheets, negotiate contract (scope, performance standard, pricing schedules, terms and conditions), announce relationship.

6. Transitioning resources; adjust team roles, compare/merge transition plans, address transition issues (communication, human resources, other production factors), meet with employees (organization and provider), make offers/termination, provide counseling and physically move.

7. Managing relationships; adjust management styles, set up oversight council, communicate, solve problems and build relationships. 


\section{Respondents}

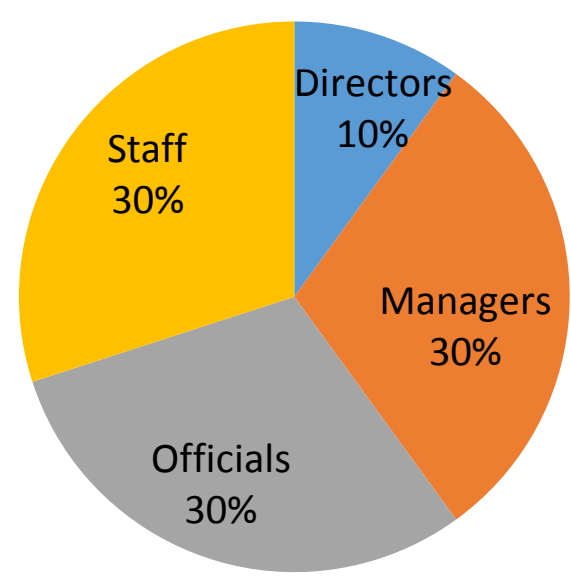

Figure 3. Percentage representation of respondents in the sample. Source: Author's field survey (2016).

\section{METHODOLOGY}

The researcher used case study to assess the effects of outsourcing in the University for Development Studies. Hence, the study combines both qualitative and quantitative research methods. The study used questionnaires as a tool for collecting the data.

Since the research was exploratory it was important to include a broad range of respondents in the sample to improve the possible generalization of the findings and reduce the likelihood of company-specific performance effects. Almost all officials whose activities involve them in outsourcing decision in the University were considered. A list of officials in the university was obtained from the Human Resources Department. All principal officers and Heads of Departments of the University that were identified were used as the population. Some of the operations were managed centrally and others too at the campuses and this reduced the size of the population of managers significantly. This centralization combined with low access in some cases resulted in a population of 55 respondents.

A structured sampling process was not possible. Other managers declined to have a questionnaire completed on their operations even though anonymity was promised. A sample of 55 managers was considered for the survey but the final sample size reduced to 33 managers. There was a response rate of $60 \%$. It is felt that even though this is an incidental sample, it represents outsourcing practices for the UDS. For inclusion in the final study it was determined that a respondent must have worked closely with at least one contract to have adequate knowledge to respond accurately. All 33 respondents had at least two contract's experience to their name. The purposive sampling method was used. Purposive or incidental sampling enables the researcher to use his judgment to select respondents which will best enable him to answer the research questions and meet his objectives. According to Welman et al. (2005) purposive sampling is the most convenient collection of members of the population that are near and readily available for research purposes.

\section{Sample distribution}

Data collection was done through a close-ended questionnaire which is a typical primary data collection method since the research was exploratory (Figure 3). Both survey methods of using either questionnaires or interviews were considered. It was felt that questionnaires would provide the better survey method. It was also felt at the time that even though interviews would give more flexibility, enable open-ended questions to be asked and thus lead to better judgment of responses (Trochim and William, 2005), they would be more expensive and more time consuming. It was also felt that a questionnaire would allow the respondent's time to formulate answers at their own convenience without feeling pressurized.

Critical outsourcing success factors for higher educational institutions are those factors that are considered most important and whose level of application/performance has had a positive correlation with overall organizational performance. The basic analysis involved the use of arithmetic mean and standard deviation which are mathematically expressed as; $\sum_{\mathbf{i}=\mathbf{0}}^{\mathbf{n}}-$, and $\left.\sqrt{\sum(\boldsymbol{x}-\boldsymbol{x}}\right)^{2}$ respectively to determine the $n$

top ten factors from the ratings by the respondents. Those factors with the highest means on importance ratings were considered to be the most critical ones to Higher Education Institutes. Those factors with the same means were ranked based on their standard deviations. Those with lower standard deviations were placed ahead of the ranks. Performance ratings below 3 were considered low and those at 4 and above were considered high. A high performance was taken to imply that a high effort was applied into implementing that factor and that the task was well done. Gaps between those regarded as being most critical and the performance thereof were calculated. Factors with huge gaps between importance and performance constituted areas for future improvement. Ordinary data from the Likert scale was considered to be interval data for the purpose of this analysis and means and standard deviations were calculated without applying a conversion factor. From the open-ended responses, themes and frequencies were drawn up. There were not many new themes raised by the respondents. These themes could also not be tested across the sample. The criticality of the 
themes could be tested in future research. On analyzing the success of outsourcing, if the level of impact was 4 and above, then outsourcing was considered to be a success on that performance dimension.

\section{RESULTS}

\section{Importance and performance on critical success factors}

The results of the important and performance on critical success factors are presented in Table 1.

\section{Success and prospects of outsourcing}

The results of the survey on the current level of success of outsourcing as well as its future prospects are indicated in the Tables 2, 3 and 4.

The standard deviations of the scores have been included to show that factors with low standard deviations have been placed above those with high standard deviations whenever the means are the same.

\section{DISCUSSION}

\section{Proposition for the success of outsourcing}

From Table 1, outsourcing was a success for $25 \%$ of the respondents. This finding supports Zineldin and Bredenlow (2003) who projected the failure rate of outsourcing to be as high as 70 percent. Sixty-one per cent felt outsourcing did not change the outsourced processes while $14 \%$ felt it negatively affected the performance of the outsourced processes. In this research the failure is above $70 \%$. Outsourcing had the most positive effect on flexibility of delivering the outsourced services to the company. The majority of respondents $(59 \%)$ felt the flexibility of their operations improved due to outsourcing.

Speed was also increased due to outsourcing: $50 \%$ felt speed of service delivery improved while $9 \%$ believed they were slowed down by outsourcing.

The cost of running the services increased after the services were outsourced: $39 \%$ of respondents found that outsourcing increased their cost compared with $33 \%$ who believed their costs were reduced. This finding supports Jiang (2005) and Bujisic et al. (2014) who found that outsourcing's target of a minimum of $15 \%$ cost saving is seldom achieved. The findings of Embleton et al. (2000) namely that a large proportion of outsourcing clients even find their costs increasing is also supported.

Overall outsourcing had a positive impact on performance with flexibility receiving the most positive impact and cost being negatively impacted. These findings show that the impact of outsourcing on cost is less than $20 \%$. The difference between 25 and $20 \%$ of the respondents is just one respondent and that is considered negligible. So it can be considered true that the success rate of outsourcing in mining is less than $20 \%$.

\section{Proposition for the future of outsourcing in the Higher Educational Institutes}

Table 2 shows that, overall, outsourcing will have a positive impact on companies' performance. Sixty per cent of respondents have a positive future view of outsourcing compared with $11 \%$ who feel otherwise. The highest impact will be on speed with the least being on cost. There is significant agreement among the respondents on outsourcing's impact on speed. Sixty-four per cent of respondents felt that the effect will be higher than average. All respondents expect the impact to be either average or above average. Even though expectations for costs remain the lowest of all performance objectives they are however positive. This suggests that the University administrators expect to improve on cost management in the future. The proposition is not supported by the findings. There is a clear indication of a bright future for outsourcing in University Administration. Managers seem to believe in the benefits of outsourcing and acknowledge their shortcomings in their implementation thereof.

\section{Research proposition 1 - Importance}

The most critical success factor as shown in Table 2 was the establishment of measurable goals and objectives for the vendor. There was strong agreement among the respondents over its importance and $88 \%$ of the respondents felt the establishment of goals and objectives was extremely important to outsourcing success. The level of agreement was so high that all respondents rated this factor higher than average. In total $97 \%$ of respondents rated the importance to be between very important and extremely important. It appears like Higher Education Institutes focus is on monitoring and control. The emphasis on control is substantiated by the importance placed on continual tracking and measurement of performance. This factor was second in importance. Fifty-eight per cent of respondents rated the importance of the factor to be extremely important. In total $97 \%$ of respondents rated the importance between very important and extremely important. No respondents rated this factor below average. Even if traditional core activities get outsourced it follows that the focus should be on controlling the vendors managing those activities. University Administrators also want it to be easy to monitor this performance. This is indicated by the 
Table 1. Percentage split of responses to importance of and performance on critical success factors.

\begin{tabular}{|c|c|c|c|c|c|c|c|c|c|c|c|c|}
\hline & \multirow{2}{*}{ Factors } & \multirow{2}{*}{$\begin{array}{l}\text { No of } \\
\text { responses }\end{array}$} & \multicolumn{5}{|c|}{ Importance } & \multicolumn{5}{|c|}{ Performance } \\
\hline & & & $1(\%)$ & $2(\%)$ & $3(\%)$ & $4(\%)$ & $5(\%)$ & $1(\%)$ & $2(\%)$ & $3(\%)$ & $4(\%)$ & $5(\%)$ \\
\hline 1 & $\begin{array}{l}\text { Ensuring that the activity can be outsourced without giving } \\
\text { away competitive advantage }\end{array}$ & 33 & 3 & 12 & 12 & 27 & 45 & 3 & 9 & 45 & 39 & 3 \\
\hline 2 & $\begin{array}{l}\text { Ensure that the client has the ability to define outsourced } \\
\text { process requirement and monitor their delivery }\end{array}$ & 33 & 3 & 0 & 3 & 27 & 67 & 3 & 12 & 42 & 21 & 21 \\
\hline 3 & $\begin{array}{l}\text { Ensure that the company's resources and capabilities } \\
\text { have gaps that can be filled can be filled by outsourcing } \\
\text { the process }\end{array}$ & 33 & 0 & 6 & 15 & 48 & 30 & 0 & 9 & 48 & 30 & 12 \\
\hline 4 & $\begin{array}{l}\text { Internal benchmarking of production and transactional } \\
\text { costs of process to be outsourced }\end{array}$ & 33 & 3 & 12 & 24 & 18 & 42 & 3 & 18 & 48 & 18 & 12 \\
\hline 5 & $\begin{array}{l}\text { Ensuring the vendor's production cost are less than the } \\
\text { client's costs }\end{array}$ & 33 & 3 & 0 & 18 & 36 & 42 & 3 & 9 & 36 & 36 & 15 \\
\hline 6 & Evaluation of risk of losing critical skills & 33 & 0 & 3 & 9 & 45 & 42 & 6 & 21 & 33 & 21 & 18 \\
\hline 7 & Evaluation of risk of access to private and sensitive data & 33 & 0 & 6 & 27 & 39 & 27 & 0 & 6 & 55 & 27 & 12 \\
\hline 8 & $\begin{array}{l}\text { Ensure that outsourcing will not have a negative cultural } \\
\text { impact }\end{array}$ & 33 & 0 & 3 & 18 & 48 & 30 & 3 & 24 & 30 & 30 & 12 \\
\hline 9 & $\begin{array}{l}\text { Benchmarking of vendors capabilities to ensure technical } \\
\text { excellence }\end{array}$ & 33 & 0 & 0 & 6 & 33 & 61 & 9 & 21 & 21 & 24 & 24 \\
\hline 10 & External benchmarking of vendor's production costs & 33 & 0 & 0 & 24 & 67 & 9 & 6 & 30 & 27 & 24 & 12 \\
\hline 11 & Ensuring cultural fit between vendor and client & 33 & 0 & 0 & 15 & 45 & 29 & 6 & 24 & 18 & 36 & 15 \\
\hline 12 & Establishment of measurable goals and objectives & 33 & 0 & 0 & 3 & 9 & 88 & 3 & 21 & 30 & 12 & 33 \\
\hline
\end{tabular}

Source: Author's field survey (2016).

importance placed on ensuring ease of monitoring vendor performance. This factor was overall fifth in importance. The importance of labour law in the Higher Education industry was highlighted by the high rating given to ensuring compliance to the Labour Relations Act during the outsourcing process. It was rated as one of the most critical success factors behind ensuring ease of monitoring vendor performance.

Risk management followed vendor's competence in importance. The assessment of outsourcing risks together with the establishment of mitigation plans for those risks were considered very important and $87 \%$ felt it was critical to evaluate the risks of losing critical skills before outsourcing. Forty-two per cent of these felt it was extremely important to evaluate this risk. Cost reduction did not feature as one of the most critical success 
Table 2. Percentage split of responses on outsourcing success.

\begin{tabular}{|c|c|c|c|c|c|c|c|c|c|c|c|}
\hline \multirow{2}{*}{ Performance measure } & \multirow{2}{*}{$\begin{array}{l}\text { No of } \\
\text { responses }\end{array}$} & \multicolumn{5}{|c|}{ Present } & \multicolumn{5}{|c|}{5 yrs from now } \\
\hline & & $1(\%)$ & $2(\%)$ & $3(\%)$ & $4(\%)$ & $5(\%)$ & $1(\%)$ & $2(\%)$ & $3(\%)$ & $4(\%)$ & $5(\%)$ \\
\hline Quality & 33 & 4 & 14 & 10 & 29 & 4 & 4 & 4 & 29 & 54 & 11 \\
\hline Flexibility & 33 & 4 & 19 & 19 & 48 & 11 & 0 & 11 & 32 & 39 & 30 \\
\hline Speed & 33 & 7 & 4 & 29 & 29 & 11 & 0 & 0 & 36 & 32 & 32 \\
\hline Cost & 33 & 7 & 32 & 29 & 29 & 4 & 4 & 21 & 36 & 32 & 9 \\
\hline Reliability & 33 & 4 & 21 & 43 & 29 & 4 & 0 & 4 & 32 & 46 & 18 \\
\hline $\begin{array}{l}\text { Overall contribution to } \\
\text { company success }\end{array}$ & 33 & 4 & 11 & 61 & 21 & 4 & 0 & 11 & 29 & 46 & 14 \\
\hline
\end{tabular}

Source: Author's field survey (2016).

Table 3. Summary of importance ranking.

\begin{tabular}{|c|c|c|c|c|}
\hline Rank & Critical success factors & $\begin{array}{c}\text { Mean } \\
\text { Score } \\
\sum_{i=0}^{n}-\bar{n} \\
\end{array}$ & $\begin{array}{c}\begin{array}{c}\text { Standard } \\
\text { Deviation }\end{array} \\
\frac{\sqrt{\sum(x-\overline{\mathbf{x}})^{2}}}{n-1}\end{array}$ & Theory \\
\hline 1 & Establishment of measurable goals and objectives & 4.85 & 0.44 & Relationship management \\
\hline 2 & Continual tracking and Measurement of performance & 4.55 & 0.56 & Relationship management \\
\hline 3 & Benchmarking of vendor capabilities & 4.55 & 0.62 & Resource-based theory \\
\hline 4 & $\begin{array}{l}\text { Ability to define and monitor delivery of outsourced } \\
\text { process }\end{array}$ & 4.55 & 0.83 & Core competency \\
\hline 5 & Ensure ease of monitoring vendor performance & 4.42 & 0.61 & $\begin{array}{l}\text { Relationship management-agency } \\
\text { theory }\end{array}$ \\
\hline 6 & Compliance with Labour Relations Act & 4.39 & 0.79 & Stakeholder management \\
\hline 7 & $\begin{array}{l}\text { Vendors access to a broad base of experienced and } \\
\text { skilled workers }\end{array}$ & 4.30 & 0.73 & Resource-based theory \\
\hline 8 & Vendors understanding of client's business & 4.30 & 0.81 & Vendor selection \\
\hline 9 & Risk of losing critical skills & 4.27 & 0.76 & Risk management \\
\hline 10 & Contingency and mitigation plans & 4.27 & 0.80 & Risk management \\
\hline
\end{tabular}

Source: Author's field survey (2016).

factors for outsourcing in Higher Education Institutes. This seems to contradict Franceschini et al. (2003) and their assertion that cost efficiency is one of the most important drivers for outsourcing choices. Cost efficiency is not one of the most important considerations in Higher Education Institutes. One respondent felt cost is totally unimportant while $78 \%$ rated cost's importance between very important and extremely important. The least important factors were the selection of a single vendor to manage the outsourced process and providing incentives to remaining employees. It has been shown that core competency management is one of the critical success factors. It's important to note though that 'core' no longer rests on the Higher Education Institutes processes but on the way these processes are managed. It has also been shown that a vendor relationship between a vendor and a client is important but not critical. Communication with affected employees is also considered important but not critical to outsourcing success. Proposition 1 is thus partially supported.

\section{Research proposition 2 - Performance}

Table 3 indicate that the general performance of respondents on all the critical success factors was just above average; a mean of 3 is average performance. There were no major performance differences among the factors. It suggests that the managers were not sure which areas to focus on. Under vendor selection the most effort was applied on ensuring compatibility between vendor and client operations: $51 \%$ of respondents rated their performance between very good and excellent: $21 \%$ rated themselves excellent. Overall it was a good performance. Performance on the other vendor selection factors was just above average as shown in Tables 4, 3 , 2 and 1 . Overall the performance on vendor selection is good. There are no constructs of vendor selection whose 
Table 4. Summary of best performance factors.

\begin{tabular}{|c|c|c|c|c|}
\hline Rank & Factors & Score & Standard deviation & Theory \\
\hline 1 & Compliance with Labours Relations Act & 3.85 & 0.91 & Stakeholder management \\
\hline 2 & $\begin{array}{l}\text { Compatibility between vendor and clients } \\
\text { operations }\end{array}$ & 3.61 & 0.97 & $\begin{array}{l}\text { Vendor selection- Resource } \\
\text { based theory }\end{array}$ \\
\hline 3 & Selection of single vendor & 3.55 & 0.97 & Vendor selection \\
\hline 4 & $\begin{array}{l}\text { Continual tracking and } \\
\text { measurement of performance }\end{array}$ & 3.55 & 1.03 & Relationship management \\
\hline 5 & Continual communication with stakeholders & 3.55 & 1.12 & Stakeholder management \\
\hline 6 & Considering local Vendors & 3.52 & 0.87 & Vendor selection \\
\hline 7 & $\begin{array}{l}\text { Ensuring vendors production costs are less than } \\
\text { clients }\end{array}$ & 3.52 & 0.97 & $\begin{array}{l}\text { Vendor selection Neoclassical } \\
\text { theory }\end{array}$ \\
\hline 8 & Ensure ease of monitoring vendor performance & 3.52 & 1.00 & Relationship management \\
\hline 9 & $\begin{array}{l}\text { Establish measurable goals } \\
\text { and objectives }\end{array}$ & 3.52 & 1.25 & Relationship management \\
\hline 10 & Ensure strategic fit between vendor and client & 3.47 & 0.95 & $\begin{array}{l}\text { Vendor selection- Resource based } \\
\text { theory }\end{array}$ \\
\hline
\end{tabular}

Source: Author's field survey (2016).

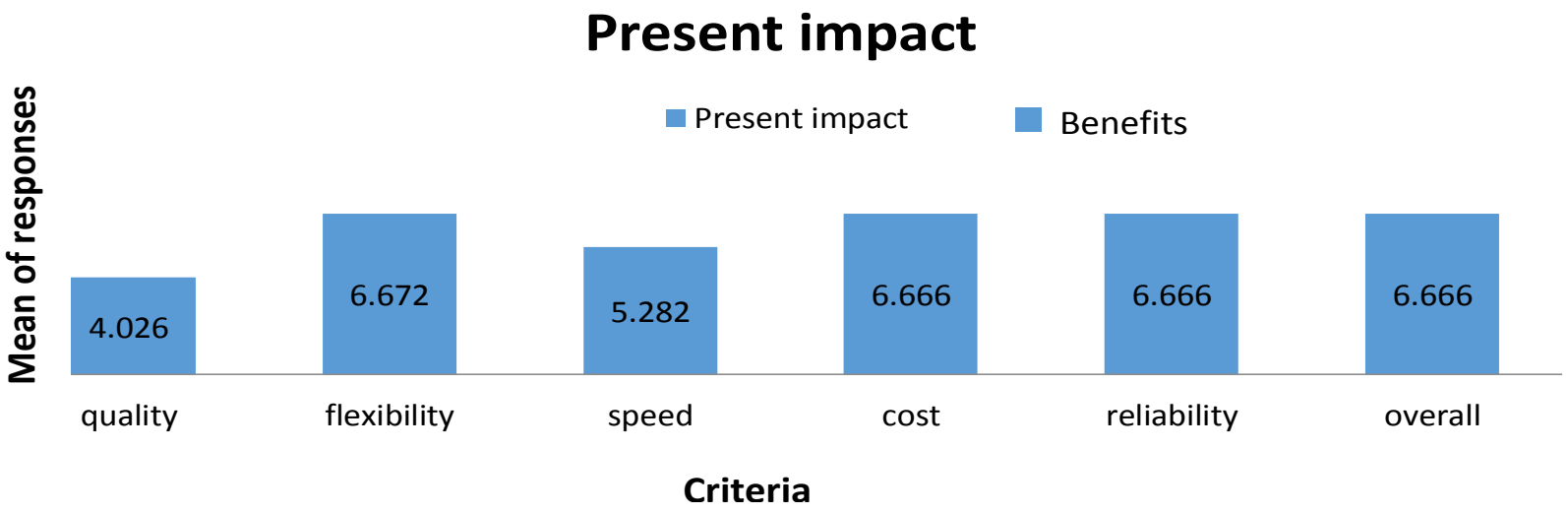

Figure 4. Current impact of outsourcing on University Administration. Source: Author's field survey (2016).

performance was below average. Featuring in the top ten performances are the selection of a single vendor, ensuring vendor's local presence and ensuring strategic fit between vendor and client. The majority of respondents $(54 \%)$ ensured in most cases that they selected a single vendor while $12 \%$ performed poorly on this factor. On ensuring vendor's local presence $41 \%$ of respondents performed well. The majority of respondents felt their performance on ensuring strategic fit with the vendor was average while $35 \%$ felt it was above average.

With regard to taking care of employees affected by outsourcing, mines' performance was slightly above average. The majority of respondents (53\%) had average performances on providing counseling to employees affected by outsourcing. There was an almost $52 / 48$ split between those who performed above average and those below average. Only $9 \%$ performed excellently in this regard. On providing performance incentives to remaining employees the majority of respondents $(70 \%)$ either did not provide any incentives or provided minimal incentives. The overall performance of the mines was slightly below average. Even though the universities failed to provide incentives, they did ensure a high compliance with the Labour Relations Act. The majority of the respondents, $63 \%$, ensured high compliance. This suggests that it is fear of the law rather than a willingness to care for affected employees that drive mines in this regard. The majority of respondents, $45 \%$, also did well on ensuring continual communication during and after the outsourcing process. It appears then that the affected employees were not neglected even though they might not have been given incentives.

Overall, mines put the least effort into providing performance incentives to remaining employees. This could be because this factor was also considered to be one of the least important with a mean of 3.4 as shown in Figure 4.

Factors that received the greatest attention were the 


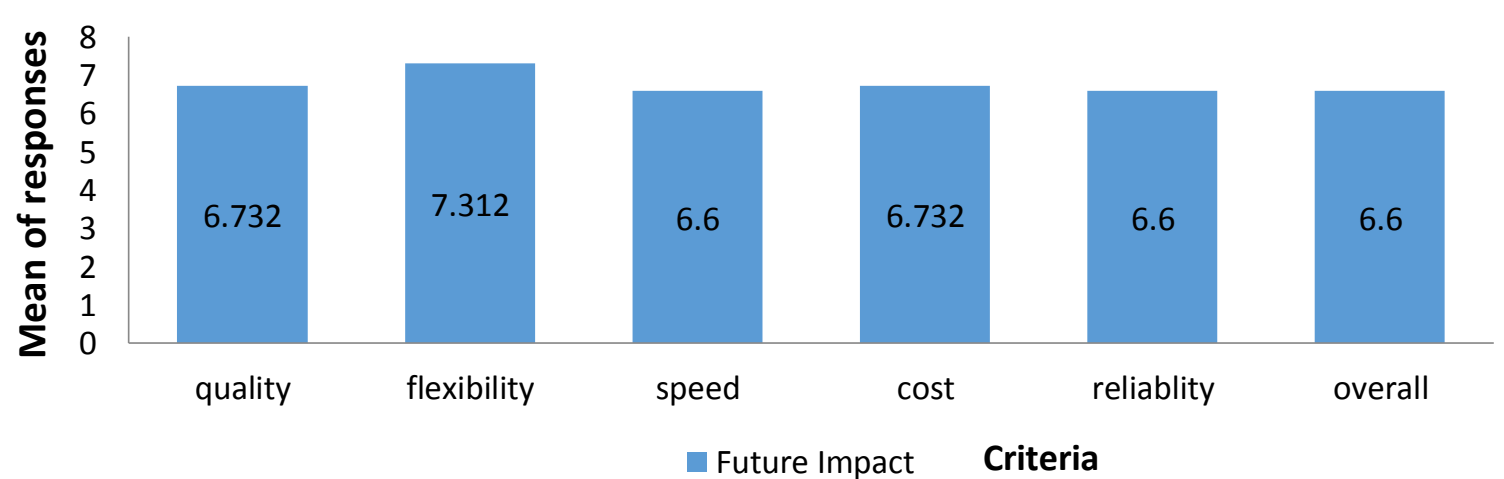

Figure 5. Future impact of outsourcing on University Administration. Source: Author's field survey (2016).

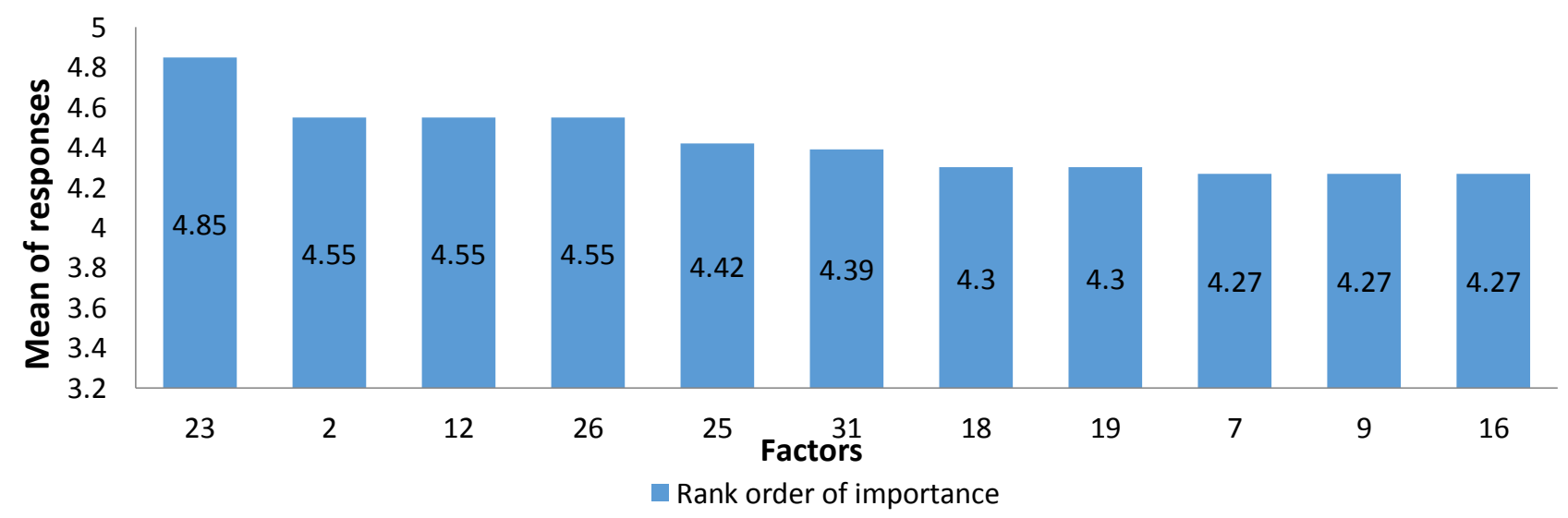

Figure 6. Rank order of critical success factors showing the top ten most important factors. Source: Author's field survey (2016).

continual tracking and measurement of performance, cost reduction, ease of monitoring of vendor and the establishment of measurable goals and objectives. Performance on continual tracking and measurement of performance was third in overall performance ranking. This is one factor the importance of which closely equates to the effort put into it: $48 \%$ of respondents performed well in this regard while $21 \%$ feel they do an excellent job in this area. Ease of monitoring vendor performance and the establishment of measurable goals and objectives received almost similar levels of attention. They were ranked 8th and 9th respectively. More effort was put into cost reduction than was put into monitoring actions mentioned above. Performance on ensuring that vendor's production costs are less than the client's costs was 7th in the performance rank. The majority of respondents, $51 \%$, put a high effort into this measure while $12 \%$ did not put much effort into this factor. These findings clearly refute the proposition. It is clear that there is just an above average performance on vendor selection and the same level of performance in addressing the welfare of employees affected by outsourcing. Higher Education Institutes perform better at addressing the welfare of employees affected by outsourcing than is expected. They also perform worse at vendor selection than is expected of them.

\section{CONCLUSION AND RECOMMENDATION}

Management's efforts in managing outsourcing are being applied to areas of low importance. There are no significant differences in the amount of effort applied to factors of significantly differing importance. The establishment of measurable goals and objectives as the most important factor is supposed to be performed close to excellently, yet it is only 9th in performance ratings. The tracking and measuring of performance which is second in importance receives a high proportion of managers' attention. It is fourth in the performance ratings. The benchmarking of vendor capabilities to ensure technical excellence is third in importance but receives minimal attention from managers. It does not even feature in the top ten best performed factors. It is also interesting to note that there is more effort placed on selecting a single vendor than the selection of a single vendor is worth. Managers have high future expectations for cost efficiency due to outsourcing and yet they do not 


\section{Rank order on Performance}

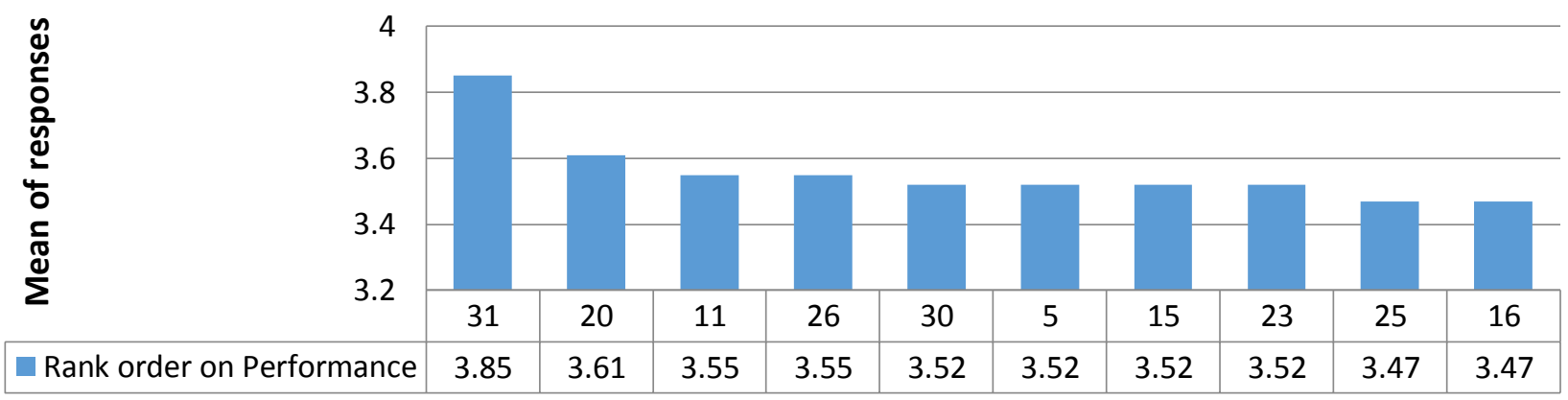

Figure 7. Rank order of performance on all factors showing where the most effort was done. Source: Author's Field Survey (2016).

\begin{tabular}{|c|c|c|}
\hline High & $\begin{array}{l}\text { FOCUS AREAS } \\
\text { 1. Establish measurable goal and objectives } \\
\text { 2. Regularly track andmeasure performance } \\
\text { 3. Benchmarkvendor capabilities } \\
\text { 4. Ability to define and monitor service } \\
\text { deliverables } \\
\text { 5. Simplify monitoring of vendor's } \\
\text { performance }\end{array}$ & $\begin{array}{l}\text { MAINTAIN } \\
\text { 1. Ensure strategic direction fit with vendor } \\
\text { 2. Communicate continually during the } \\
\text { outsourcing process } \\
\text { 3. Ensure cultural fit with vendor } \\
\text { 4. Establish a comprehensive contract } \\
\text { 5. Involve senior managementin review } \\
\text { meetings }\end{array}$ \\
\hline 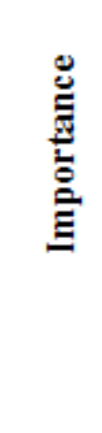 & $\begin{array}{l}\text { LOWW PRIORITY } \\
\text { 1. Selecting a single vendor. } \\
\text { 2. Providing incentives to remaining } \\
\text { employees. } \\
\text { 3. Provide a flexible contract. } \\
\text { 4. Benchmark vendors production costs } \\
\text { 5. Provide counseling to affected } \\
\text { employees. } \\
\text { 6. Benchmarking of costs associated with } \\
\text { the process to be outsourced. }\end{array}$ & $\begin{array}{l}\text { REDUCE EMPHASIS } \\
\text { 1. Ensure compatibility with vendor's } \\
\text { operations. } \\
\text { 2. Comply with labour relations Act. } \\
\text { 3. Hiring local vendors. } \\
\text { 4. Ensuring that vendors costs are less than } \\
\text { yours. } \\
\text { 5. Employ weighting of criteria to evaluate } \\
\text { vendors. } \\
\text { 6. Preventing vendors access to private and } \\
\text { sensitive data. }\end{array}$ \\
\hline
\end{tabular}

Figure 8. Performance model. Source: Author's field survey (2016).

view the importance of measures to ensure that vendors have lower costs than theirs. This suggests that managers do not seem to see cost efficiency coming from ensuring that vendors' input costs are less than theirs, but more from improved monitoring of vendor performance and from improvements in other performance dimensions. These findings seem to suggest that the low impact of outsourcing stems from lack of knowledge of the critical factors and the failure of companies to focus on these areas.

In general Higher Education Institutes put a lot of effort where it is not really needed. They put the same level of effort into all areas. It suggests that they are not aware of areas that give them the most benefit. Applying the same level of effort in most areas does not seem to be helping, judging by the mediocre benefits that were achieved from outsourcing.

It is clear from the results that companies are not putting the right amount of effort into the areas that matter to outsourcing success as shown in figures 5,6 and 7. It is argued that a holistic approach is required to manage outsourcing. The fact that a number of critical success factors have been identified does not mean that other factors cease to matter. What it means is that if an operation is not doing well in these areas then their outsourcing would most definitely fail. Based on the findings the model shown in Figure 8 is recommended for use in improving outsourcing in Higher Education 
Institutes. This model places all university operations' outsourcing under one umbrella. It is generalizing the Higher Education Institutes industry's outsourcing shortcomings and strengths based on findings. Some operations might be able to identify very closely with the model and some not. The top left and right bottom quadrants represent those factors gold mines currently need to work on to improve their outsourcing. Most effort should go into the top left hand factors to move them to the top right quadrant. The items in the top right quadrant do not all signify the critical success factors. Universities that are performing well in those factors should just maintain their current efforts. Different operations will need to look at the factors in the four quadrants. If they are putting too much emphasis on low importance factors then they need to redirect that effort to factors in the top two quadrants

\section{REFERENCES}

Arnold U (2000). New dimensions of outsourcing: a combination of transaction cost economics and the core competencies concept. Eur. J. Purch. Supply Manage. 6:23-29.

Barthelemy JG (2001). The hidden costs of IT outsourcing. Sloan Manage. Rev. 42(3):60-69.

Bujisic M, Hutchinson J, Parsa HG (2014). The effects of restaurant quality attributes on customer behavioral intention, Int. J. Contemp. Hosp. Manage. 26(8):1270-1291.

Campbell JD (2005). Outsourcing in Maintenance Management: A valid alternative to self-provision. J. Qual. Maintenance Eng., MCB University Press. New York. pp. 18-24.

Davies W (2000). Understanding Strategy. Strategy and Leadership, MCB University Press. New York. pp. 25-30.

Ellram L, Billington C (2001). Purchasing Leverage Considerations in the Outsourcing Decision, Eur. J. Purch. Supply Manage. 7(1):15-27.

Embleton PR (2000). A practical guide to successful outsourcing (ADI Limited, Fredericton, New Brunswick, Canada).

Embleton PR, Wright PC (2000). A Practical guide to successful outsourcing. Empowerment in Organizations, MCB University Press. New York. pp. 94-106.

Farrington B, Lysons K (2006). Purchasing and Supply Chain Management $7^{\text {th }}$ Edition ISBN-13: 978-0273694380, ISBN-10: 9780273694380 .
Fill C, Visser E (2000). The outsourcing dilemma: a composite approach to the make or buy decision. Management decision, pp. 4350. MCB University Press. New York.

Franceschini F, Galetto M, Pignatelli A, Varetto M (2003). Outsourcing: guidelines for a structured approach. Benchmarking: MCB University Press Limited. New York. An int. J. pp. 246-260.

Gottschalk P, Hans Solli-saether (2005). Managing Successful IT Outsourcing Relationships IRM Press ISBN 10: 1591407605 ISBN 13: 9781591407607.

Greaver R (2001). Corporate strategy. A Resource-based Approach, McGraw-Hill. New York.

Horngren $T$ (2000). Livestock Artificial Insemination Technology: Paperback LI QING HONG. REN YOU SHE, Publisher: China Press (January 1 1st, 2000 ), ISBN-10: 7508231333, ISBN-13: 9787508231334.

Jennings D (2002). "Strategic management: an evaluation of the use of three learning methods", J. Manage. Dev. 21(9):655-665. https://doi.org/10.1108/02621710210441658.

Jiang $\mathbf{J}$ (2005). Detection of high-affinity and sliding clamp modes for MSH2-MSH6 by single-molecule unzipping force analysis. Mol. Cell 20(5):771-81.

Leavy B (2004). "Outsourcing strategies: opportunities and risks", Strateg. Leadersh. 32(6):20-25.

Linder JC (2004). "Outsourcing as a strategy for driving transformation", Strateg. Leadersh. 32(6):26-31.

Porter MF (2000). Location, Competition, and Economic Development: Local Clusters, pp. 197-287.

Tayles M, Drury C (2001). An empirical investigation of the importance of cost-plus pricing. Chris Guilding School of Accounting and Finance, Griffith University, Southport, Australia Huddersfield University Business School, Huddersfield, UK, www.emeraldinsight.com/0268-6902.htm.

Thompson JB, Martin H (2001). Managing Change: Thomas Nelson \& Sons Ltd.ISBN-10: 0174232306, ISBN-13: 978-0174232308 Stock Image.

Trochim K, William M (2005). Research Methods: The Concise Knowledge Base Atomic Dog Pub., 2005.

Welman C, Kruger F, Mitchell B (2005). "Research Methodology," Oxford University Press, Oxford, p. 146.

Zineldin M, Bredenlow T (2003). Strategic Outsourcing: A Structured Approach to Outsourcing Decisions and Initiatives Hardcover-Bargain Price, AMACOM (March 8, 1999), ISBN-10: 0814404340.

http://sciencewebpublishing.net/jerr 